\title{
Gene rearrangement and Chernobyl related thyroid cancers
}

\author{
M Santoro', GA Thomas², G Vecchio', GH Williams², A Fusco', G Chiappetta1, V Pozcharskaya ${ }^{3}$, TI Bogdanova $^{4}$, \\ EP Demidchik ${ }^{3}$, ED Cherstvoy ${ }^{3}$, L Voscoboinik ${ }^{4}$, ND Tronko ${ }^{4}$, A Carss ${ }^{2}$, H Bunnell2, M Tonnachera ${ }^{5}$, J Parma ${ }^{5}$, \\ JE Dumont ${ }^{5}$, G Keller ${ }^{6}$, H Höfler ${ }^{6}$ and ED Williams ${ }^{2}$ \\ ${ }^{1}$ Centro di Endocrinologia ed Oncologia Sperimentale del CNR c/o Dipartimento di Biologia e Patologia Cellulare e Moleculare, Universita di Napoli, Italy; \\ ${ }^{2}$ Thyroid Carcinogenesis Group, University of Cambridge, Strangeways Research Laboratory, Wort's Causeway, Cambridge CB1 4RN, UK; ${ }^{3}$ Minsk State \\ Medical Institute, Minsk, Belarus; ${ }^{4}$ Institute of Endocrinology and Metabolism, Kiev, Ukraine; ${ }^{5}$ IRIHBN, Free University of Brussels, Belgium, ${ }^{6}$ Institute for \\ Pathology, Technical University of Munich, Germany
}

Summary The increase in thyroid carcinoma post-Chernobyl has been largely confined to a specific subtype of papillary carcinoma (solid/follicular). This subtype is observed predominantly in children under 10 in unirradiated populations, but maintains a high frequency in those aged 10-15 from those areas exposed to fallout from the Chernobyl accident. The aim of this study was to link morphology with molecular biology. We examined 106 papillary carcinomas from children under the age of 15 at operation. All were examined for rearrangements of the RET oncogene by reverse transcription polymerase chain reaction (RT-PCR); a subset of these cases were also examined for mutations of the three ras oncogenes, exon 10 of the thyroid stimulating hormone receptor, associated more usually with a follicular rather than papillary morphology, and exons 5, 6, 7 and 8 of the p53 gene, commonly involved in undifferentiated thyroid carcinoma. Rearrangements of the RET oncogene were found in $44 \%$ of papillary carcinomas in which we studied fresh material; none of the tumours examined showed mutation in any of the other genes. The two rearrangements resulting from inversion of part of chromosome 10 (PTC1 and PTC3) accounted for the majority of RET rearrangements identified, with PTC1 being associated with papillary carcinomas of the classic and diffuse sclerosing variants and PTC3 with the solid/follicular variant. (C) 2000 Cancer Research Campaign

Keywords: thyroid cancer; Chernobyl; gene rearrangement; ref; oncogenes

The accident at the Chernobyl nuclear power plant on 26 April 1986 resulted in the population of Southern Belarus and Northern Ukraine being exposed to radioactive fallout which contained substantial amounts of radioactive iodine. It became apparent in 1992 that there was an increase in childhood thyroid carcinoma (Baverstock et al, 1992; Kazakov et al, 1992). Thyroid carcinoma in children is usually rare (of the order of $0.3-1.3$ million $^{-1}$ year $^{-1}$; Parkin et al, 1988). The first reaction to the increase in thyroid carcinoma was one of surprise, due largely to the reported size of the increase and the short latent period. However, a number of published studies support the view that the tumours are causally related to exposure from Chernobyl (Likhtarev et al, 1995; Williams, 1996; Jacob et al, 1998).

Two morphologically distinct types of differentiated carcinoma derive from the thyroid follicular cell, papillary carcinoma and follicular carcinoma. The two different types exhibit not only different morphology but also different biological behaviour and are associated with mutations in different oncogenes; papillary carcinoma with rearrangement of either the RET or trk oncogenes (Greco et al, 1992; Santoro et al, 1992) and follicular carcinoma with mutation of the ras oncogene (Lemoine et al, 1989). Mutations of exon 10 of the thyroid stimulating hormone (TSH)

Received 24 March 1999

Revised 22 July 1999

Accepted 25 August 1999

Correspondence to: GA Thomas receptor have been particularly associated with a specific type of benign thyroid tumour, the hot nodule (Parma et al, 1995), but there have been reports of TSH receptor mutation in follicular carcinoma (Russo et al, 1995). The p53 oncogene is commonly mutated in many different types of carcinoma; in thyroid carcinoma it is associated with anaplastic carcinoma, rather than the differentiated types of thyroid carcinoma (Ito et al, 1992).

The majority of the rise in post-Chernobyl thyroid carcinoma incidence has been due to an increase in papillary carcinoma. However, papillary carcinoma in children can be subdivided into three main subtypes, solid/follicular, classical and diffuse sclerosing variant (Harach and Williams, 1995). The morphological characteristics of any tumour result from the integration of the molecular biological changes involved in the genesis of that tumour. In this study we have therefore correlated the morphological findings with molecular biological analysis of mutation in four oncogenes associated with thyroid carcinogenesis (RET, ras, p53 and exon 10 of the TSH receptor).

\section{METHODS}

\section{Verification of pathology}

All material was provided by the Institute of Pathology in Minsk and the Institute of Endocrinology and Metabolism in Kiev. Sections from representative paraffin blocks from each of the cases examined were stained with haematoxylin and eosin (H\&E), and with a standard immunocytochemical techique for calcitonin 
and thyroglobulin. Papillary carcinomas were classified as either solid/follicular, classical or diffuse sclerosing variant based on their dominant morphological component, using definitions given in our previous study of the morphology of childhood thyroid cancer in England and Wales (Harach and Williams, 1995). Where possible, frozen sections of unfixed material for DNA and RNA extraction were also examined to determine the presence and amount of tumour epithelium in the frozen material.

A total of 132 cases were used for this molecular biological study. Fresh material was available in 50 cases; analyses were performed on paraffin sections for the remaining 82 cases. All cases were operated in Minsk or Kiev between 1990 and 1996. Serial paraffin sections were cut at one centre and circulated to the other centres for extraction and analysis of the various oncogenes. Paraffin material was only available from those cases operated in 1990-1994, fresh material was available from cases operated in 1995 and 1996. DNA and RNA from fresh material was extracted at one centre using a standard Trizol ${ }^{\mathrm{TM}}$ protocol. Aliquots were distributed to other centres for analysis of RET rearrangement, mutation of the TSH receptor, $\mathrm{Ki}, \mathrm{Ha}, \mathrm{N}$ ras and p53 oncogenes.

\section{RT-PCR for RET/PTC expression}

Reverse transcription and subsequent PCR amplification was performed on both paraffin and fresh material as previously reported. The sequence of the forward primers used were: for RET/PTC1: 5'-ATTGTCATCTCGCCGTTC-3', specific for the H4 gene, and for RET/PTC3: 5'-AAGCAAACCTGCCAGTGG-3', specific for the elel gene. The sequence of the reverse primer was: 5'-TGCTTCAGGACGTTGAAC-3', specific for RET tyrosine kinase. One microgram of RNA was reverse transcribed using the reverse primer and, following the addition of the forward primer, subjected to 40 cycles of PCR $\left(94^{\circ} \mathrm{C}\right.$ for $30 \mathrm{~min}, 55^{\circ} \mathrm{C}$ for $2 \mathrm{~min}$ and $72^{\circ} \mathrm{C}$ for $2 \mathrm{~min}$ ). The product of the reaction was analysed on a $2 \%$ agarose gel and hybridized with a probe for the RET tyrosinekinase domain. The HPRT specific primers were: $5^{\prime}$-CCTGCTGGATTACATCAAAGCACTG-3' (forward), corresponding to the nucleotides $316-340$ of the third exon of the human gene; 5'-CCTGAAGTATTCATTATAGTCTCAAGG-3' (reverse) corresponding to the nucleotides $685-661$ of the eighth exon of the human gene.

\section{RT-PCR method for detecting expression of the $R E T$ tyrosine kinase domain (TK) and extracellular domain (EC)}

The reverse transcription reaction was performed on $1 \mu \mathrm{g}$ of RNA. The RT reaction was performed in a final volume of $25 \mu \mathrm{l}$ containing 0.1 optical density units of random hexamers (Pharmacia $\mathrm{P}(\mathrm{N}) 6), 2.5 \mu \mathrm{l}$ of $10 \times \mathrm{RT}$ buffer $(1 \times \mathrm{RT} 50 \mathrm{~mm}$ Tris- $\mathrm{HCl}$ (pH 8.3), $50 \mathrm{~mm}$ potassium chloride ( $\mathrm{KCl}), 4 \mathrm{~mm}$ dithiothreitol (DTT), $10 \mathrm{~mm}$ magnesium chloride $\left.\left(\mathrm{MgCl}_{2}\right)\right), 2.5 \mu \mathrm{l}$ of $10 \mathrm{~mm}$ dNTPs, 1 unit $\mu \mathrm{l}^{-1}$ RNasin and 200 units $\mathrm{ml}^{-1}$ of super RT and incubated at $41^{\circ} \mathrm{C}$ for $60 \mathrm{~min}$. The reaction was terminated at $95^{\circ} \mathrm{C}$ for $5 \mathrm{~min}$. Fifteen microlitres of the reaction mixture were used for PCR amplification with primers 5'-CACCGGATGGAGAGGCCAGACAACTGCAGC-3' and $5^{\prime}$-ACCGGCCTTTTGTCCGGCTC-3' (TK), and5'-GTGCAGTTCTTGTGCCCCAACATCAG-3' and 5'-CCCAGCGCGTGCTCACCT-3' (extracellular) in a final volume of $100 \mu \mathrm{l}$. Primers for the $3^{\prime}$ end of the RET oncogene (TK) corresponded to exon $16,5^{\prime}$ upstream and exon 17 , $3^{\prime}$ downstream spanning a $1150 \mathrm{bp}$ intron, primers for the extracellular domain were designed to span intron 4 , giving a product from RNA of $106 \mathrm{bp}$. PCR reactions consisted of 35 cycles of amplification at $95^{\circ} \mathrm{C}$ for $30 \mathrm{~s}, 50^{\circ} \mathrm{C}$ for $30 \mathrm{~s}$ and $72^{\circ} \mathrm{C}$ for $1 \mathrm{~min}$. Precautions were taken to prevent PCR contamination. Parallel reagent negative controls were run with all samples to exclude generalized PCR contamination. $15 \mu \mathrm{l}$ of each PCR reaction was run on a $2 \%$ agarose gel together with $\varnothing X$ markers. The specificity of the PCR product was confirmed by Southern blotting using a probe specific for $3^{\prime}$ region of the RET gene.

S6 ribosomal mRNA was used as a reporter target for amplification to monitor the presence of RNA; a negative amplification result indicated RNA degradation. The primers 5'-AATCCGCAAACGTTTCAATCTCT-3' and 5'-TGAATCTTGGGTGCTTTGGTCCTA-3' were chosen in different exons to generate a $106 \mathrm{bp}$ PCR product from mRNA, readily distinguished from S6 genomic amplification which would result in a PCR product of $1826 \mathrm{bp}$. Amplification was performed for 35 cycles using the same conditions as for RET TK and extracellular PCRs. RNA extracted from the SHSY neuroblastoma cell line, which expresses c-RET, was used as a positive control. RNA extracted from the 293 kidney cell line, which does not express c-RET was used as a negative control, together with conventional no template controls. Both cell lines were kindly provided by Professor Bruce Ponder (Human Cancer Genetics Group, University of Cambridge).

\section{TSH receptor mutation}

Paraffin sections were washed in xylene and ethanol. After vacuum drying of the pellet, proteinase $\mathrm{K}\left(1 \mathrm{mg} \mathrm{ml}^{-1}\right)$ in $50 \mathrm{~mm}$ Tris buffer was added at $55^{\circ} \mathrm{C}$ for $2 \mathrm{~h}$ and then at $37^{\circ} \mathrm{C}$ overnight. After heating the sample for $10 \mathrm{~min}$ at $100^{\circ} \mathrm{C}$ to inactivate the proteinase $\mathrm{K}$, the quality of the DNA was checked on a $0.8 \%$ agarose gel, which showed the presence of high molecular weight DNA after ethidium bromide staining.

Two fragments (bases 2078-2664 and bases 1273-2340) of the TSH receptor gene were amplified by PCR and subjected to double-strand direct sequencing. The antisense primer was biotinylated in each case. The PCR reaction was performed in a final volume of $100 \mathrm{ml}$, containing $2 \mathrm{ml}$ of DNA, $50 \mathrm{mM} \mathrm{KCl}$, $10 \mathrm{~mm}$ Tris- $\mathrm{HCl} \mathrm{pH} 8.3,1.5 \mathrm{~mm} \mathrm{MgCl}_{2}, 0.01 \%$ gelatin, $0.2 \mathrm{~mm}$ dNTP, 5 U Taq polymerase (Boehringer Mannheim, Germany) and $200 \mathrm{nM}$ of each primer. Samples were denatured at $93^{\circ} \mathrm{C}$ for $2 \mathrm{~min}$ for the first pair of primers followed by 50 cycles of $93^{\circ} \mathrm{C}$ for 1 $\min , 54^{\circ} \mathrm{C}$ for $1 \mathrm{~min}$ and $72^{\circ} \mathrm{C}$ for $2 \min 30 \mathrm{~s}$. A final extension of $6 \mathrm{~min}$ at $72^{\circ} \mathrm{C}$ was performed. The protocol for the second pair of primers differed by using an annealing temperature of $50^{\circ} \mathrm{C}$ rather than $53^{\circ} \mathrm{C}$. PCR products were visualized by ethidium bromide staining on agarose gels; a strong band of the expected size (600 bp) was observed by using the first pair of primers, while a faint band of the expected size (1000 bp) was observed with the second pair of primers. PCR negative control (water instead of DNA template) and the material obtained by using a paraffin block devoid of tissue did not show any amplification. Mutations in the TSH receptor amplimers were identified by single-strand conformation polymorphism (SSCP), and confirmed by sequencing.

For DNA from frozen specimens, four fragments of the TSH receptor gene were amplified by PCR and subjected to doublestrand direct sequencing. The fragments and the primers used 
were: A; residues 235-294, forward primer 5'-M13D TCA TCT CCC AAT TAA CCT CAG G-3'; reverse primer 5'-T7 GCT TCC AAT TTC CTC TCC AC-3'; fragment B, residues 430-537 forward primer 5'-T7 TTC GTT AGT CTG CTG GCT C-3', reverse primer 5'-M13D CAA CCA TGA TGG CAC ATG-3'; fragment $\mathrm{C}$ : residues 526-646, forward primer $5^{\prime}$-M13D CTG GTA TGC CAT CAC CTT-3', reverse primer 5'-M13R TGA GAG GCT TGT TCA GAA TT-3'; fragment D: residues 635-stop forward primer 5'-M13D TGT TGA TCT TCA CCG ACT TC-3', reverse primer 5'-M13R TAA GTT CCC CTA CCA TTG TG-3' $\{\mathrm{M} 13 \mathrm{D}, \mathrm{M} 13 \mathrm{R}$ and $\mathrm{T} 7$ correspond to universal sequencing primers (ABI) $\}$. Standard PCR was carried out in a $20 \mu$ volume containing $200 \mathrm{ng}$ DNA, $50 \mathrm{~mm} \mathrm{KCl}, 10 \mathrm{~mm}$ Tris- $\mathrm{HCl}$, pH 8.3, $2 \mathrm{~mm}$ for fragment $\mathrm{A}$, or $1 \mathrm{~mm}$ for fragment $\mathrm{B}, \mathrm{C}$ and $\mathrm{D}$ of $\mathrm{MgCl}_{2}$, $0.01 \%$ gelatine, $0.2 \mathrm{~mm}$ dNTP, $5 \mathrm{U}$ Taq polymerase (BRL) and $300 \mathrm{nM}$ for fragment A, $150 \mathrm{nM}$ for fragment B and D or $100 \mathrm{nM}$ for fragment $\mathrm{C}$ of each primer. The annealing temperatures were $61^{\circ} \mathrm{C}$ for fragment $\mathrm{A}, 52^{\circ} \mathrm{C}$ for fragments $\mathrm{B}, 50^{\circ} \mathrm{C}$ for $\mathrm{C}$ and $48^{\circ} \mathrm{C}$ for $\mathrm{D}$ respectively. Direct genomic DNA sequencing of both strands was realized with the dye primer cycle sequencing core kit (ABI: PN 402070) and mutations searched for by Factura and Sequence Navigator Software running on an ABI 373 sequencer.

\section{Ras gene mutation}

Tumours were microdissected from paraffin-embedded sections. Following digestion with proteinase $\mathrm{K}\left(200 \mathrm{mg} \mathrm{ml}^{-1}\right)$ at $55^{\circ} \mathrm{C}$ overnight, PCR was performed in a final volume of $50 \mu \mathrm{l}$ containing $50 \mathrm{~mm} \mathrm{KCl}, 10 \mathrm{~mm}$ Tris- $\mathrm{HCl}(\mathrm{pH} 8.4), 100 \mathrm{~g} \mathrm{ml}^{-1}$ gelatin, $0.2 \mu \mathrm{M}$ of each primer, $200 \mu \mathrm{mol}$ of each of dATP, dCTP, dGTP and dTTP and 2.5 units of Taq polymerase. Exons 1 and 2 of each of the 3 ras genes ( $\mathrm{Ha}, \mathrm{Ki}$ and $\mathrm{N}$ ) were amplified. The primer pairs used and PCR conditions for each gene are given in Table 1. Following a hot start of $95^{\circ} \mathrm{C}$ for $3 \mathrm{~min}, 35$ cycles of PCR were performed consisting of $95^{\circ} \mathrm{C}$ for $30 \mathrm{~s}, 48-50^{\circ} \mathrm{C}$ for $30 \mathrm{~s}$ and $72^{\circ} \mathrm{C}$ for $1 \mathrm{~min}$ followed by a final extension step of $72^{\circ} \mathrm{C}$ for $6 \mathrm{~min}$. One of each of the primer pairs was biotinylated; direct sequencing of the product was carried out using the Dynal and Sequenase 2.0 kits.

\section{p53 mutation analysis}

Tissue was microdissected from tumour areas with at least $50 \%$ tumour. Paraffin-embedded tissues were dewaxed with xylene, washed with ethanol, vacuum-desiccated, resuspended in $200 \mu \mathrm{l}$ $50 \mathrm{mmol} \mathrm{l}^{-1}$ Tris- $\mathrm{HCl} \mathrm{pH} 8.5,1 \mathrm{mmol} \mathrm{l}^{-1}$ EDTA, 0.5\% Tween-20, $0.2 \mathrm{mg} \mathrm{ml}^{-1}$ proteinase $\mathrm{K}$ and incubated at $55^{\circ} \mathrm{C}$ for at least $3 \mathrm{~h}$. Proteinase $\mathrm{K}$ was inactivated by boiling for $10 \mathrm{~min}$. Two microlitres of 1:10 dilution were directly used for PCR.
The most conserved regions of the p53 gene comprising exons 5-8 were amplified by PCR as described (Lohmann et al, 1993) with the exception that exons 6 and 8 were amplified without nested PCR using only the external primers for the corresponding exons.

PCR products were diluted 1:2 with $95 \%$ formamide, $10 \mathrm{~mm}$ sodium hydroxide $(\mathrm{NaOH}) \quad 0.05 \%$ xylene cyanol, $0.05 \%$ bromophenol blue, denatured at $95^{\circ} \mathrm{C}$ for $5 \mathrm{~min}$ and chilled on ice. Electrophoresis was performed for each exon under four different running conditions including those previously found to give optimal resolution determined from known p53 mutations which had been identified by direct sequencing (Lohmann et al, 1993). In brief, $5 \mu \mathrm{l}$ of denatured PCR product were loaded on a horizontal $8 \%$ polyacrylamide gel (30:05) containing $2 \%$ glycerine in a $20 \mathrm{~mm}$ MOPS (pH 8.0), $1 \mathrm{~mm}$ EDTA running buffer (TGGE system, Diagen, Düsseldorf, Germany). In addition, electrophoresis was performed in a discontinuous borate-phosphatebuffer system using $90 \mathrm{~mm}$ Tris-borate as running buffer and 8\% polyacrylamide gels containing $2 \%$ glycerol prepared in a $90 \mathrm{~mm}$ Tris-phosphate buffer ( $\mathrm{pH}$ 8.0). Electrophoresis was performed at $15^{\circ} \mathrm{C}$ and $25^{\circ} \mathrm{C}$ for exons $5-8$ and at $5^{\circ} \mathrm{C}$ and $15^{\circ} \mathrm{C}$ for exon 6 . Visualization of DNA was performed by silver staining. Gels were washed and fixed in $10 \%$ ethanol, $0.5 \%$ acetic acid for $10 \mathrm{~min}$, stained with $0.1 \% \mathrm{AgNO}_{3}$ for $10 \mathrm{~min}$, washed in distilled water and developed in $1.5 \% \mathrm{NaOH}, 0.15 \%$ formaldehyde and $0.01 \%$ $\mathrm{NaBH}_{4}$.

Analysis of p53 mutation and mutation in the ras oncogenes were performed on paraffin material only; analysis of RET expression was performed on frozen material only.

\section{RESULTS}

The majority (128/132) of the cases studied were papillary carcinomas, three were follicular carcinomas and one was a medullary carcinoma. The majority (74\%) of the papillary carcinomas were of the solid/follicular subtype, which is the commonest subtype of papillary carcinoma post-Chernobyl (Bogdanova et al, 1996; Cherstvoy et al, 1996; Williams, 1996) (Table 2). Of the 106 papillary carcinomas which produced amplifiable RNA and were analysed for RET rearrangement using rearrangement specific RTPCR, 20 were identified as positive for PTC1 and 15 for PTC3; one other tumour was positive for both PTC1 and PTC3. Examples of these results are given in Figures 1 and 2. Analysis of the expression of the extracellular and tyrosine kinase domains was also performed independently in a different institute in 45 of the 106 cases. Twenty-two of these 45 tumours were positive for expression of RET tyrosine kinase. No tumour sample showed positivity for the expression of the RET extracellular domain, suggesting that the

Table 1 Primer pairs and PCR conditions for amplification of ras oncogenes

\begin{tabular}{|c|c|c|c|c|}
\hline Region & Sense $5^{\prime}-3^{\prime}$ & Antisense $5^{\prime}-3^{\prime}$ & $\begin{array}{l}\text { Annealing } \\
\text { temperature }\end{array}$ & $\begin{array}{l}\mathrm{MgCl}_{2} \\
\text { concn. }\end{array}$ \\
\hline $\mathrm{K}$ ras exon 1 & GACTGAATATAAACTTGTGG & CTATTGTTGGATCATATTCG & $52^{\circ} \mathrm{C}$ & $1.5 \mathrm{~mm}$ \\
\hline $\mathrm{K}$ ras exon 2 & AAGTAGTAATTGATGGAGAA & CATGTACTGGTCCCTCATT & $52^{\circ} \mathrm{C}$ & $2.5 \mathrm{~mm}$ \\
\hline $\mathrm{H}$ ras exon 1 & GACGGAATATAAGCTGGTGGTG & CTATAGTGGGGTCTGATTCG & $48^{\circ} \mathrm{C}$ & $1.5 \mathrm{~mm}$ \\
\hline $\mathrm{H}$ ras exon 2 & AGGTGGTCATTGATGGGGAG & CATGTACTGGTCCCGCATG & $48^{\circ} \mathrm{C}$ & $1.5 \mathrm{~mm}$ \\
\hline $\mathrm{N}$ ras exon 1 & ATGACTGAGTACAAACTGGT & CTATGGTGGGATCATATTCA & $50^{\circ} \mathrm{C}$ & $1.5 \mathrm{~mm}$ \\
\hline $\mathrm{N}$ ras exon 2 & AGGTGGTTATAGATGGTGAA & CATGTATTGGTCTCTCATG & $48^{\circ} \mathrm{C}$ & $1.5 \mathrm{~mm}$ \\
\hline
\end{tabular}


Table 2 Histology of post-Chernobyl thyroid carcinomas examined for mutation of various oncogenes

\begin{tabular}{lcc}
\hline Type of material & Fixed material only & Frozen material \\
\hline Total number of tumours & 82 & 50 \\
No. papillary carcinomas & 80 & 48 \\
No. not analysable & 19 & 3 \\
No. analysed & 61 & 45 \\
Subtype of papillary carcinoma in the & & \\
tumours analysed & $46(75 \%)$ & $32(71 \%)$ \\
Solid/follicular & $15(25 \%)$ & $11(25 \%)$ \\
Classic or diffuse sclerosing variant & 0 & $2(4 \%)$ \\
Insufficient to subclassify & & \\
\end{tabular}

a Nucleic acid of inadequate quality.

$\begin{array}{llllllllllllllll}\text { A } & 1 & 2 & 3 & 4 & 5 & 6 & 7 & 8 & 9 & 10 & 11 & 12 & 13 & 14 & 15\end{array}$

B
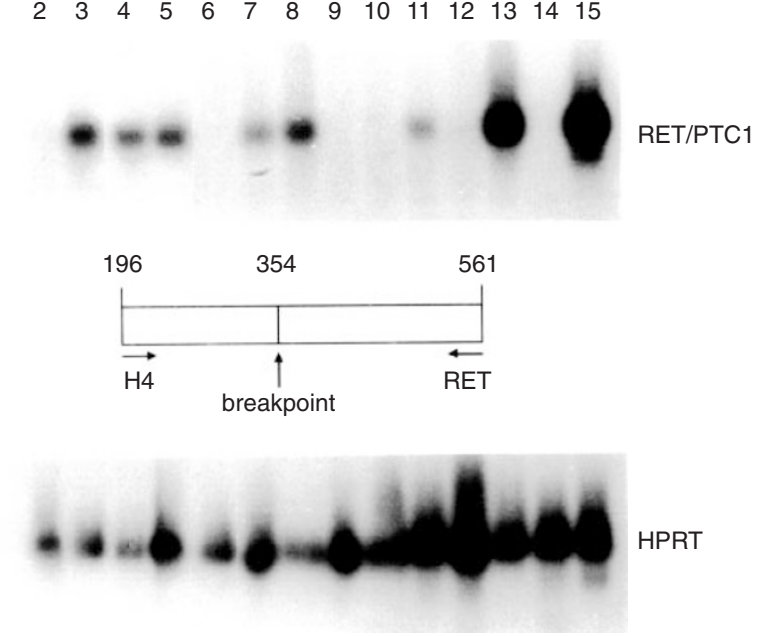

Figure 1 RET/PTC1 detection in Chernobyl papillary thyroid carcinomas. (A) RNAs were amplified with RET/PTC1-specific primers, as indicated in the schematic diagram, subjected to electrophoretic separation on a $2 \%$ agarose gel, and hybridized with a RET probe covering its TK domain. Lane 1: a negative control represented by RNA from the TPC cell line (a human papillary carcinoma cell line spontaneously expressing a RET/PTC1 oncogene) subjected to PCR without previous reverse-transcription. Lane 2: another negative control represented by normal thyroid RNA; lanes 3-14: representative examples of RNAs from papillary thyroid carcinomas from the Chernobyl area showing seven positive samples. Amplification of the RNAs without previous reverse transcription gave negative results (data not shown). Lane 15: a positive control represented by RNA extracted from the TPC cell line. (B) The same RNAs were subjected to RT-PCR amplification using HPRT (human phosphoribosyl transferase)-specific primers. The products of the amplification were run on a $2 \%$ agarose gel and hybridized to an HPRT-specific probe. This confirmed that the negative results were not due to absence of amplifiable RNA

RET tyrosine kinase expression was due to the presence in these tumours of a RET rearrangement fusing the RET tyrosine kinase domain of the c-RET gene with an active promoter. Among these 45 cases investigated for $R E T$ tyrosine kinase expression, there were 20 with an identified PTC1 or -3 rearrangement, including one tumour which showed both PTC1 and $-3 ; 18$ showed RET tyrosine kinase expression. The unexpected negative RET tyrosine kinase in two cases may be the result of a lack of sensitivity. Twenty-five cases lacked either a PTC1 or -3 rearrangement, 21 were negative for RET tyrosine kinase expression, while four were
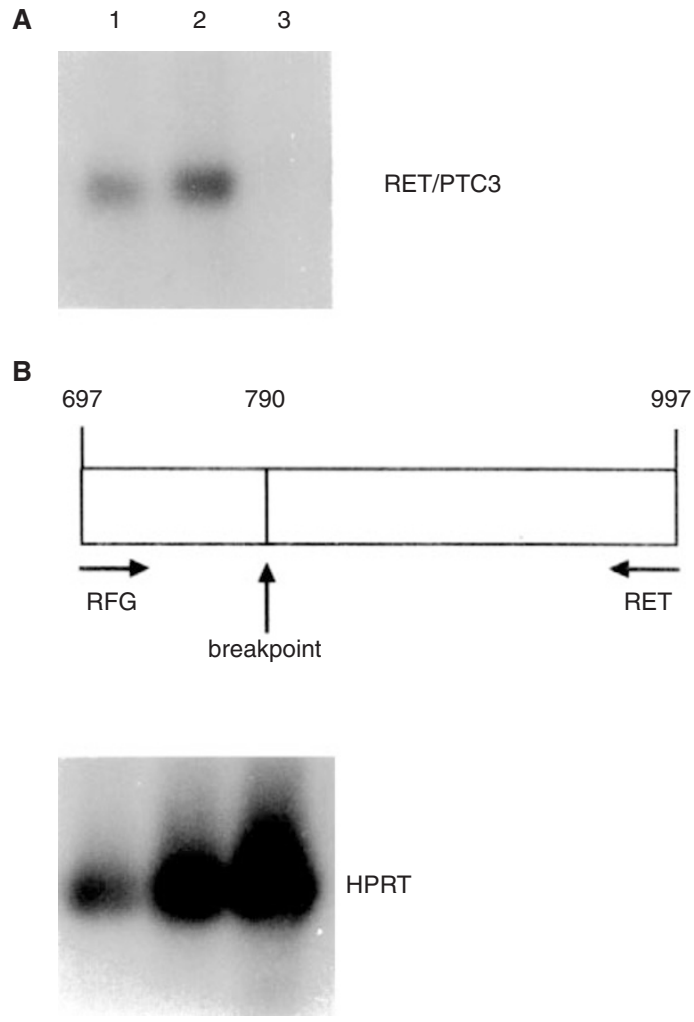

Figure 2 RET/PTC3 detection in Chernobyl papillary thyroid carcinomas. (A) RNAs were amplified with RET/PTC3 specific primers, as indicated in the schematic diagram, subjected to electrophoretic separation on a $2 \%$ agarose gel, and hybridized with a RET probe covering its TK domain. Lanes 1-2: two representative cases scored positive for RET/PTC3 expression. Lane 3: a negative control represented by normal thyroid RNA. (B) The same RNAs were subjected to RT-PCR amplification using HPRT (human phosphoribosyl transferase)-specific primers. The products of the amplification were run on a $2 \%$ agarose gel and hybridized to an HPRT-specific probe

positive. The positive RET tyrosine kinase in these four cases could result from the presence of a RET rearrangement other than PTC1 or -3 , for example those described by Fugazzola et al (1995) and Klugbauer et al $(1995,1998)$. Overall agreement between the two techniques was therefore present in 39 out of 45 cases $(87 \%)$.

We have compared the frequency of detection of RET rearrangement in formalin-fixed paraffin-embedded material with that from fresh tissue, but due to availability of material were only able to do that by comparing the frequency in different groups of tumours, not in identical tumours (Table 3). Adequate RNA was available 
Table 3 Identification of PTC1 or -3 rearrangement of the ret oncogene from formalin-fixed, paraffin-embedded and frozen material

\begin{tabular}{lcc}
\hline Type of material & $\begin{array}{c}\text { Fixed material } \\
\text { (cases operated 1990-1994) }\end{array}$ & $\begin{array}{c}\text { Frozen material } \\
\text { (cases operated 1995-1996) }\end{array}$ \\
\hline No. papillary carcinomas & 80 & 48 \\
No. not analysable ${ }^{a}$ & 19 & 3 \\
No. analysed & 61 & 45 \\
PTC1 & 13 & 7 \\
PTC3 & 3 & 12 \\
PTC1 and PTC3 & 0 & 1 \\
Negative for PTC1 or -3 & 45 & 25 \\
\hline
\end{tabular}

${ }^{a}$ RNA of inadequate quality.

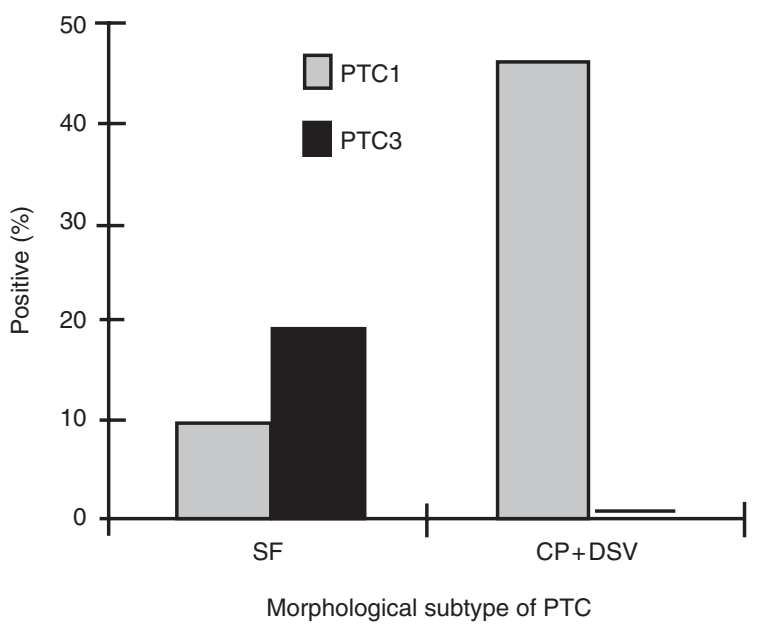

Figure 3 Association of different ret rearrangements with morphological subtypes of papillary carcinoma

from paraffin sections of 61 tumours resected from 1990 to 1994. Sixteen were positive for RET rearrangement (13 PTC1 and three PTC3). Adequate RNA was available from fresh tissue from 45 cases resected in 1995-1996; these are the same group in which RET TK expression was compared with RET rearrangement. Of these 45 cases, 20 showed RET rearrangement, eight PTC1 and 13 PTC3 (one tumour had both rearrangements).

The type of RET rearrangement correlated with the morphological type of papillary carcinomas, with PTC3 being found more commonly in those of solid/follicular morphology, and PTC1 found in the less common classic papillary and diffuse sclerosing variant of papillary carcinoma (see Figure 3).

No mutations in any of the ras genes, exon 10 of the TSH receptor or in exons 6,7 or 8 of the p53 gene were identified in any tumour (Table 4).

\section{DISCUSSION}

We present the results of a comprehensive study of a large series of post-Chernobyl papillary carcinomas studying a range of different types of oncogenes in a large series of tumours, and comparing these findings to detailed morphology.

RET gene rearrangements have been reported in about one-third of adult papillary carcinomas not known to be radiation related, but were not found in any other type of thyroid carcinoma (Santoro et al, 1992). One study of thyroid tumours in adult patients with
Table 4 Oncogene involvement in post- Chernobyl papillary carcinomas

\begin{tabular}{lrccc}
\hline & No. studied & No. positive & No. negative & \% positive \\
\hline ret rearrangement & 106 & 36 & 70 & 34 \\
ret TK expression & 46 & 23 & 23 & 50 \\
TSHR & 57 & 0 & 57 & 0 \\
p53 & 35 & 0 & 35 & 0 \\
Ki & 31 & 0 & 31 & 0 \\
N & 23 & 0 & 23 & 0 \\
Ha & 23 & 0 & 23 & 0 \\
\hline
\end{tabular}

Rearrangement of the ret oncogene was assessed in two ways; by identification of the PTC1 and PTC3 rearrangement and also by expression of the $3^{\prime}$ end of the c-ret gene in the absence of expression of the extracellular domain. Exon 10 of the TSH receptor, exons 5, 6, 7 and 8 of the p53 gene, together with codons 12, 13 and 61 of the ras oncogenes were examined for mutation. Ret rearrangement was analysed on both frozen (cases operated in 1995-96) and paraffin material (cases operated in 1990-4). Ret TK expression was carried out on frozen material only. TSHR mutation was carried out on a subset of both paraffin and frozen material. The remaining oncogenes were examined in paraffin specimens only.

a history of external radiation found that ret rearrangements occurred in follicular adenomas as well as papillary carcinomas (Bounacer et al, 1997). A more recent study, which reported findings on children exposed to fallout from the Chernobyl accident found that ret rearrangement was restricted to papillary carcinomas; no rearrangement of this gene was observed in follicular tumours (Thomas et al, 1999). In the majority of studies of tumours not known to be related to radiation exposure, ret rearrangement has been found only in papillary carcinomas. In a study of 21 cases of papillary carcinoma from children under 15 at operation in England and Wales $47 \%$ showed expression of the RET oncogene suggesting the presence of a rearrangement (Williams et al, 1996). The relative frequency of the two major subtypes of ret rearrangement (PTC1 and -3) varies in studies which report their incidence post-Chernobyl. In two small studies of Chernobyl-related thyroid cancer, one with four cases with rearrangement and one with nine, PTC3 was the commonest type of RET rearrangement found (Fuggazola et al, 1995; Klugbauer et al, 1995). In a larger study, 33 of 38 selected cancers from patients under the age of 18 from Belarus showed a RET rearrangement, 22 of these were PTC3 (Nikiforov et al, 1997). In the most recent reported study of 51 cases under 16 at operation, 25 papillary carcinomas showed a ret rearrangement, with an almost equal frequency of the two types of rearrangement (Smida et al, 1999). We have found both PTC1 and -3 in these 106 cases, all under 15 at operation, but have also shown that the two commonest $R E T$ 
rearrangements, PTC1 and -3 , show an association with different morphologies of papillary carcinoma, PTC1 being more common in tumours with a classical or diffuse sclerosing phenotype and PTC3 more common in papillary carcinomas with a solid/follicular phenotype $\left(P<0.001 \chi^{2}\right.$ test $)$, in agreement with and extending the earlier conclusions of Nikiforov et al (1997) who showed that papillary tumours with a solid architecture from exposed children had a high prevalence of PTC3 rearrangement. This correlation might be related to the level of RET TK expression in the two rearrangements, or to an influence of the gene to which the RET TK is fused, or to an effect related to the reciprocal breakpoint. However, transgenic mice which have a thyroid targetted expression of the PTC1 or -3 rearrangement also show the same association between morphology and expression of the different RET rearrangements, with PTC1 transgenic animals showing tumours of classical papillary morphology (Jhiang et al, 1996; Santoro et al, 1996) and PTC3 transgenic mice showing tumours of predominantly solid morphology (Powell et al, 1998). The finding that the inappropriate expression of the same tyrosine kinase in these animals results in an alteration of the morphology of the tumours produced suggests a morphogenetic role for the gene to which the RET tyrosine kinase is fused.

The differing frequencies of RET rearrangement found in the series of cases which we analysed on paraffin and the series analysed from frozen cannot be explained by differing frequencies of papillary carcinomas with solid/follicular morphology within the two series; $75 \%$ of the papillary carcinomas analysed were of this morphology in the paraffin series and $71 \%$ in the frozen series. The difference in the frequency of PTC3-positive tumours is more likely to reflect either the technical difficulty of analysing paraffin material or possibly a change in the molecular biology of postChernobyl carcinoma with time; the paraffin series were from patients operated in 1990-1994, and the frozen material was from patients operated in 1995 and 1996. A recent study by Smida et al (1999) using frozen samples only, suggests that the ratio of PTC3:PTC1 drops with time post-Chernobyl. However, this report does not provide detailed histological analysis, so we do not know whether these changes correlate with changes in the morphology of tumours studied in the two time periods. Other studies have shown that PTC1 rearrangement is more common in papillary carcinoma from adults with a radiation history (Bounacer et al, 1997), but whether this is related to age of patient at exposure to radiation or the histological subtype of papillary carcinoma warrants further investigation. Only one of our cases showed both PTC1 and -3 rearrangement, contrasting with a recent study using a similar technique (RT-PCR followed by Southern hybridization) which found that multiple rearrangements were not infrequent in papillary carcinomas in adults (Sugg et al, 1998).

TSH receptor pathway mutations are common in hyperfunctioning follicular tumours, but have rarely been found in papillary carcinomas (Challeton et al, 1995; Ohno et al, 1995; Parma et al, 1995; Waldman and Rabes, 1997). p53 mutations have been largely confined to undifferentiated thyroid carcinomas (Ito et al, 1992). There have been two recent reports suggesting that germline polymorphisms of the p53 gene in exon 6 and intron 6 may be found occasionally in the Belarussian population (Hillebrandt et al, 1997; Smida et al, 1997); one study failed to demonstrate oncogenic p53 mutations in post-Chernobyl papillary carcinomas (Suchy et al, 1998), while another found them in only $6 \%$ (Nikiforov et al, 1996). Our findings therefore suggest that the pattern of oncogene involvement in the Chernobyl-related cancers correlates with the morphological type, and shows a similar frequency to that found in studies of thyroid cancer generally.

The lack of any ras gene mutation needs discussion. Most earlier studies used slot blot and mutation specific oligonucleotide hybridization and found a significant proportion, up to $62 \%$, of papillary carcinomas with a ras mutation (Suarez et al, 1990). The difference from our findings could be related to age, environmental or genetic factors, or to the techniques used. One study using Southern blotting and hybridization (Shi et al, 1991) and another using PCR and direct sequencing (Manenti et al, 1994) failed to find any ras mutations in papillary carcinomas. Slot blot techniques could be detecting mutations in tumour subpopulations, while PCR and sequencing techniques may fail to detect mutations because of the presence of excess stromal tissue. Our techniques used careful microdissected tumour samples, detected ras mutations in the expected proportion of pancreatic and thyroid follicular carcinomas and reliably detected ras mutations if they were present in more than $40 \%$ of the tumour cells (data not shown). In agreement with our findings, Suchy et al (1997) found no ras mutations in post-Chernobyl childhood thyroid carcinomas. One previous study has suggested that Ki-ras mutation in follicular carcinomas may be related to radiation exposure (Wright et al, 1991) and another that it may occasionally occur in radiation-associated papillary carcinomas (Challeton et al, 1995). In a separate study of 26 UK childhood papillary carcinomas, we found no mutations in any of the three ras genes (data not shown). It would therefore appear that ras is not involved in childhood papillary carcinomas whether they are of radiation aetiology or not. We conclude that in follicular carcinogenesis point mutation in a ras gene can be an early event, as it has been identified in adenomas as well as carcinomas (Lemoine et al, 1989; Suarez et al, 1990; Wright et al, 1991). In papillary carcinogenesis rearrangement of the RET gene is an early event, as immunohistochemistry shows RET gene overexpression in a proportion of both small and large papillary carcinomas (Viglietto, 1995), and there is no morphological evidence of any precursor lesion for papillary carcinoma.

While papillary carcinomas are associated with RET rearrangements and follicular carcinomas with ras mutations, in neither case are these present in all tumours. Other point mutations, including mutations in gsp, and TSHr have been found in follicular tumours (Challeton et al, 1995; Parma et al, 1995; Russo et al, 1995). In papillary tumours rearrangements of the trk oncogene have been found in a small minority of cases (Grieco et al, 1992; Beimfohr et al, 1999), two further rearrangements of the RET oncogene have recently been defined in post-Chernobyl thyroid cancer (Fugazzola et al, 1996; Klugbauer et al, 1998), and it is likely that the majority, possibly the great majority of papillary carcinomas are associated with a chromosome rearrangement. Among mutagens radiation is particularly prone to give double-strand DNA breaks leading to deletions and rearrangements (Sankaranarayanan, 1991), lesions that form only a minority of chemical mutagen-induced or naturally occurring mutations. Irradiation of cultured thyroid tumour cells has been shown to be capable of causing RET rearrangements (Ito et al, 1993).

We suggest that the restriction of the thyroid tumour increase so far seen to one type of carcinoma is not related to the ability of radiation to cause one specific mutation, but to the general ability of radiation to induce gene rearrangements; those arrangements 
that are oncogenic to the thyroid will lead to clonal expansion. In this case rearrangements that activate the RET or trk tyrosine kinases can stimulate growth and lead to papillary carcinoma, the particular type of thyroid carcinoma found. There is as yet no convincing evidence that radiation is specifically linked to a particular type of RET rearrangement, and different selection factors for different RET rearrangements could operate at different ages. The relative lack of follicular carcinomas may be linked to the association of the early stages of follicular carcinogenesis with point mutations rather than gene rearrangements, or to a longer latent period, perhaps related to progression through an adenoma.

There is an interesting parallel with the situation in leukaemia, where the main type linked with radiation exposure, chronic myeloid leukaemia, is associated with an abnormal karyotype with a 9:22 translocation in virtually every case, while in chronic lymphatic leukaemia, not known to be related to exposure to radiation the majority of typical cases lack any detectable karyotypic abnormality (Woessner et al, 1996).

Our findings show that there is no doubt that a major increase of childhood thyroid carcinoma has occurred in the area around Chernobyl, and that it is currently restricted to one type of differentiated tumour. Molecular biology investigations correlate with the morphology, and show that papillary carcinoma can be regarded as especially associated with gene rearrangement while follicular carcinoma is associated with point mutation. We suggest that the current restriction of the increase to papillary carcinoma is linked to the particular effectiveness of radiation in causing doublestrand breaks and gene rearrangements.

\section{ACKNOWLEDGEMENTS}

This work was supported by EC contracts numbers COSU CT93 0049, COSU CT CT94 0089 and FI4C CT96 003. We gratefully acknowledge the help of Mrs B Wilson, Mrs S Davies and Mrs H Cook for preparation of the histological material.

\section{REFERENCES}

Baverstock K, Egloff B, Pinchera A, Ruchti C and Williams D (1992) Thyroid cancer after Chernobyl. Nature 359: 21-22

Beimfohr C, Klugbauer S, Demidchik EP, Lengfelder E and Rabes HM (1999) NTRK1 rearrangement in papillary thyroid carcinomas of children after the Chernobyl reactor accident. Int J Cancer 80: 842-847

Bogdanova T, Bragarnik M, Tronko ND, Harach HR, Thomas GA and Williams ED (1996) The pathology of thyroid cancer in Ukraine post-Chernobyl. In: The Radiological Consequences of the Chernobyl Accident, Karaoglou A, Desmet G, Kelly GN and Menzel HG (eds), pp. 785-789. European Commission EUR $16544 \mathrm{EN}$

Bounacer A, Wicker R, Caillou B, Cailleux AF, Sarasin A, Sclumberger M and Suarez HG (1997) High prevalence of activating ret proto-oncogene rearrangements from patients who had received external radiation. Oncogene 15: $1263-1273$

Challeton C, Bounacer A, Du Villard JA, Caillou B, De Vathaire F, Monier R, Schlumberger M and Suarez HG (1995) Pattern of ras and gsp oncogene mutations in radiation-associated human thyroid tumors. Oncogene 11: 601-603

Cherstvoy E, Pozcharskaya V, Harach HR, Thomas GA and Williams ED (1996) The pathology of childhood thyroid carcinoma in Belarus. In: The Radiological Consequences of the Chernobyl Accident, Karaoglou A, Desmet G, Kelly GN and Menzel HG (eds), pp. 779-784. European Commission EUR $16544 \mathrm{EN}$

Fuggazzola L, Pilotti S, Pinchera A, Vorontsova TV, Mondellini P, Bongarzone I, Greco A, Astakhova L, Butti MG, Demidchik EP, Pacini F and Pierotti MA (1995) Oncogenic rearrangements of the ret proto-oncogene in papillary thyroid carcinomas from children exposed to the Chernobyl nuclear accident. Cancer Res 55: 5617-5620
Grieco A, Pierotti MA, Bongarzone I, Pagliardini J, Lanzi C and Della Porta G (1992) Trk-T1 is a novel oncogene formed by the fusion of TPR and Trk genes in human papillary cancer. Oncogene 7: 237-242

Harach HR and Williams ED (1995) Childhood thyroid cancer in England and Wales. Br J Cancer 72: 777-783

Hillebrandt S, Streffer C, Demidchik EP, Biko J and Reiners C (1997) Polymorphisms in the 533 gene in thyroid tumours and blood samples of children from areas in Belarus. Mutat Res 381: 201-207

Ito T, Seyama T, Mizuno T, Tsuyama N, Hayashi T, Hayashi Y, Dohi K, Nakamura N and Akiyama M (1992) Unique association of p53 mutations with undifferentiated but not with differentiated carcinomas of the thyroid gland. Cancer Res 52: 1369-1371

Ito T, Seyama T, Iwamoto KS, Hayashi T, Mizuno T, Tsuyama N, Dohi K, Nakamura $\mathrm{N}$ and Akiyama M (1993) In vitro irradiation is able to cause RET oncogene rearrangement. Cancer Res 53: 2940-2943

Ito T, Seyama T, Iwamoto KS, Mizuno T, Tronko ND, Komissarenko IV, Cherstvoy ED, Satow Y, Takiechi N, Dohi K and Akiyama M (1994) Activated ret oncogene in thyroid cancers of children from areas contaminated by Chernobyl accident. Lancet 344: 259

Jacob P, Goulko G, Heidenrich WF, Likhtarev I, Kairo I, Tronko ND, Bogdanora TI, Kenigsberg J, Buglova E, Drozdovitch V, Goloneva A, Demidchik EP, Balanov M, Zvonova I and Beral V (1998) Thyroid risk to children calculated. Nature 392: $31-32$

Jhiang SM, Sagartz JE, Tong Q, Parker TJ, Capen CC, Cho JY, Xing S and Ledent C (1996) Targetted expression of the ret/PTC1 oncogene induces papillary thyroid carcinomas. Endocrinology 137: 375-378

Kazakov VS, Demidchik EP and Astakhova LN (1992) Thyroid cancers after Chernobyl. Nature 359: 21

Klugbauer S, Lengfelder E, Demidchik EP and Rabes HM (1995) High prevalence of ret rearrangement in thyroid tumors of children from Belarus after the Chernobyl reactor accident. Oncogene 11: 2459-2467 5620

Klugbauer S, Demidchik EP, Lengfelder E and Rabes HM (1998) Detection of a novel type of ret rearrangement (PTC5) in thyroid carcinomas after Chernobyl and analysis of the involved ret-fused gene RFG5. Cancer Res 58: 198-203

Lemoine NR, Mayall ES, Wyllie FS, Williams ED, Goyns M, Stringer BMJ and Wynford-Thomas D (1989) High frequency of ras oncogene activation in all stages of human thyroid tumorigenesis. Oncogene 2: 159-164

Likhtarev IA, Sobolev BG, Kairo IA Tronko ND, Bogdanova TI, Olenic VA, Epshtein EV and Beral V (1995) Thyroid cancer in Ukraine. Nature 375: 365

Lohmann D, Putz B, Reich U, Bohm J, Prauer H and Hofler H (1993) Mutational spectrum of the p53 gene in human small-cell lung cancer and relationship to clinicopathological data. Am J Pathol 142: 907-915

Manenti G, Pilotti S, Re FC, Della Porta G and Pierotti MA (1994) Selective activation of ras oncogenes in follicular and undifferentiated thyroid carcinomas. Eur J Cancer 30A: 987-993

Nikiforov YE, Nikiforova MN, Gnepp DR and Fagin JA (1996) Prevalence of mutations of ras and p53 in benign and malignant thyroid tumors from children exposed to radiation after the Chernobyl nuclear accident. Oncogene 13: 687-693

Nikiforov YE, Rowland JM, Bove KE, Monforte-Munoz H and Fagin JA (1997) Distinct pattern of ret oncogene rearrangements in morphological variants of radiation-induced and sporadic thyroid papillary carcinomas in children. Cancer Res 57: 1690-1694

Ohno M, Endo T, Ohta K, Gunji K and Onaya T (1995) Point mutations in the thyrotropin receptor in human thyroid tumors. Thyroid 5: 97-100

Parkin DM, Stiller CA, Bieber A, Draper GJ, Terracini B and Young YL (eds) (1988) International Incidence of Childhood Cancer. IARC Scientific Publications No 87. International Association for Research an Cancer: Lyon

Parma J, Van Sande J, Swillens S, Tonacchera M, Dumont J and Vassart G (1995) Somatic mutations causing constitutive activity of the thyrotropin receptor are the major cause of hyperfunctioning thyroid adenomas: identification of additional mutations activating both the cyclic adenosine $33^{\prime}, 5^{\prime}$-monophosphate and inositol phosphate-Ca ${ }^{2+}$ cascades. Mol Endocrinol 9: 725-733

Powell DJ, Russell J, Nibu K, Li G, Rhee E, Lioa M, Goldstein M, Keane WM, Santoro M, Fusco A and Rothstein J (1998) The ret/PTC3 oncogene: metastatic solid-type papillary carcinomas in murine thyroids. Cancer Res $\mathbf{5 8}$ : $5523-5528$

Russo D, Arturi F, Schlumberger M, Caillou B, Monier R, Filetti S and Suarez HG (1995) Activating mutations of the TSH receptor in differentiated thyroid carcinomas. Oncogene 11: 1907-1911

Sankaranarayanan K (1991) Ionizing radiation and genetic risks. III. Nature of spontaneous and radiation-induced mutations in mammalian in vitro systems and mechanisms of induction of mutations by radiation. Mutat Res 258: 75-97 
Santoro M, Carlomango F and Hay ID (1992) Ret oncogene activation in human thyroid neoplasms is restricted to the papillary cancer subtype. J Clin Invest $\mathbf{8 9}$ : $1517-1522$

Santoro M, Chiappetta G, Cerrato A, Salvatore D, Zhang L, Manzo G, Picone A, Portella G, Santelli G, Vecchio G and Fusco A (1996) Development of thyroid papillary carcinomas secondary to tissue-specific expression of the RET/PTC1 oncogene in transgenic mice. Oncogene 12: 1821

Shi YF, Zou MJ, Schmidt H, Juhasz F, Stensky V, Robb D and Farid NR (1991) High rates of ras codon 61 mutation in thyroid tumors in an iodide-deficient area. Cancer Res 51: 2690-2693

Smida J, Zitzelsberger H, Kellerer AM, Lehmann L, Minkus G, Negele T, Spelsberg F, Hieber L, Demidchik EP, Lengfelder E and Bauchinger M (1997) p53 mutations in childhood thyroid tumours from Belarus and in thyroid tumours without radiation history. Int J Cancer 73: 802-807

Smida J, Salassidisk K, Hieber L, Zitelsberger H, Kellere AM, Demidchik EP, Negele T, Spelsberg F, Lengfelder E, Weiner M and Bauchinger M (1999) Distinct frequency of ret rearrangements in papillary thyroid carcinomas of children and adults from Belarus. Int J Cancer 80: 32-38

Suarez HG, du Villard JA, Severino M, Caillou B, Schlumberger M, Tubiana M, Parmentier C and Monier R (1990) Presence of mutations in all three ras genes in human thyroid tumors. Oncogene 5: 565-570

Suchy B, Waldmann V, Klugbauer S and Rabes HM (1998) Absence of RAS and p53 mutations in thyroid carcinomas of children after Chernobyl in contrast to adult thyroid tumours. Br J Cancer 77: 952-955

Sugg SL, Ezzat S, Rosen IB, Freeman JL and Asa SL (1998) Distinct multiple ret/ptc gene rearrangements in multifocal papillary thyroid neoplasia. J Clin Endocrinol Metab 83: 4116-4122
Thomas GA, Bunnell H, Cook HA, Williams ED, Nerovnya A, Cherstvoy ED, Tronko ND, Bogdanova TI, Chiappetta G, Viglietto G, Pentimalli F, Salvatore G, Fusco A, Santoro M and Vecchio G (1999) High prevalence of RET/PTC rearrangements in Ukrainian and Belarussian post-Chernobyl thyroid papillary carcinomas: a strong correlation between RET/PTC3 and the solid/follicular variant. J Clin Endocrinol Metab (in press)

Waldmann V and Rabes HM (1997) Absence of Gs $\alpha$ gene mutations in childhood thyroid tumors after Chernobyl in contrast to sporadic adult thyroid neoplasia. Cancer Res 57: 2358-2361

Wright PA, Williams ED, Lemoine NR and Wynford-Thomas D (1991) Radiationassociated and 'spontaneous' human thyroid carcinomas show a different pattern of ras oncogene mutation. Oncogene 6: 471-473

Viglietto G, Chiappetta G, Martinez-Tello FJ, Fukunaga FH, Tallini G, Rigopoulou D, Visconti R, Mastro A, Santoro M and Fusco A (1995) RET/PTC oncogene activation is an early event in thyroid carcinogenesis. Oncogene 11: 1207-1210

Williams ED (1996) Effects on the thyroid in populations exposed to radiation as a result of the Chernobyl accident. In: One Decade After Chernobyl. IAEA: 207-230

Williams GH, Rooney S, Thomas GA, Cummins G and Williams ED (1996) RET activation in adult and childhood papillary thyroid carcinoma using a reverse transcriptase-n-polymerase chain reaction approach on archival-nested material. Br J Cancer 74: 585-589

Woessner S, Sole F, Perez-Losada A, Florensa L and Vila RM (1996) Trisomy 12 is a rare cytogenetic finding in typical chronic lymphocytic leukemia. Leuk Res 20: $369-374$ 